\title{
INFLUENCE OF THERMAL TREATMENT ON THE STABILITY \\ OF PHENOLIC COMPOUNDS AND THE MICROBIOLOGICAL QUALITY OF SUCROSE SOLUTION FOLLOWING OSMOTIC DEHYDRATION OF HIGHBUSH BLUEBERRY FRUITS
}

\author{
Anna Kucner ${ }^{1 凶}$, Agnieszka Papiewska ${ }^{1}$, Robert Klewicki ${ }^{1}$, Michał Sójka ${ }^{1}$, \\ Elżbieta Klewicka \\ ${ }^{1}$ Institute of Chemical Technology of Food, Lodz University of Technology \\ Stefanowskiego 4/10, 90-924 tódź, Poland \\ ${ }^{2}$ Institute of Fermentation Technology and Microbiology, Lodz University of Technology \\ Wólczańska 171/173, 90-924 Łódź, Poland
}

\begin{abstract}
Background. Osmotic dehydration is a process of the partial removal of water which is based on immersion of material having cellular structure in a hypertonic solution. Osmotic dehydration is used as a pretreatment for the dehydration of foods before they are subjected to further processing such as freezing, freeze drying, vacuum drying. Management of spent syrup is one of the most important problems related to osmotic dewatering. Osmotic solutions are heavily polluted with of carbohydrates, remains of the dehydrated material and microorganisms. The aim of this study was to determine the effect of thermal treatment on the content of phenolic compounds and the microbiological quality of sucrose solution used in 15 cycles of osmotic dehydration of highbush blueberry (Vaccinium corymbosum L.) fruits.

Material and methods. The tested material was $65.0 \pm 0.5^{\circ}$ Brix sucrose solution used for 15 cycles of osmotic dehydration of highbush blueberry (Vaccinium corymbosum L.). Osmotic dehydration was conducted at $40^{\circ} \mathrm{C}$ for $120 \mathrm{~min}$ using fruits previously subjected to enzymatic pretreatment. The thermal treatment of sucrose solution was conducted at $70,80,90,100$ and $115^{\circ} \mathrm{C}$ for 20,40 and $60 \mathrm{~s}$. The sucrose solution was analysed in terms of total polyphenols, particular polyphenols using high performance liquid chromatography and microbiological analysis was subjected.

Results. Thermal treatment at $70-115^{\circ} \mathrm{C}$ for $20 \mathrm{~s}$ caused degradation of $8.5 \%$ to $12.7 \%$ of polyphenols, while as much as $23.1 \%$ of polyphenols were degraded at $115^{\circ} \mathrm{C}$ after $60 \mathrm{~s}$. The present paper proposes heating parameters that are optimal from the point of view of phenolic compound retention and microbiological quality: thermal treatment of syrup at $100^{\circ} \mathrm{C}$ for $40 \mathrm{~s}$. Under these conditions, total polyphenols retention was $94.5 \%$, while the retention of individual phenolic compounds varied from $89.2 \%$ to $37.2 \%$, and that of flavan-3-ols amounted to $89.5 \%$. The studied manner of syrup treatment eliminated the problem of syrup contamination with yeasts and molds (reducing their levels to less than $1 \mathrm{CFU} / \mathrm{mL}$ ).
\end{abstract}

Key words: osmotic dehydration, blueberry, spent syrup, polyphenols, microbial contamination, thermal treatment 
Kucner A., Papiewska A., Klewicki R., Sójka M., Klewicka E., 2014. Influence of thermal treatment on the stability of phenolic compounds and the microbiological quality of sucrose solution following osmotic dehydration of highbush blueberry fruits. Acta Sci. Pol., Technol. Aliment. 13(1), 79-88.

\section{INTRODUCTION}

Highbush blueberry (Vaccinium corymbosum L.) fruits are an important source of phenolic compounds, which are thought to be natural antioxidants. According to literature data, they play a significant role in combating harmful free radicals, thus decreasing the risk of developing cardiovascular diseases [Petti and Scully 2009]. The major groups of polyphenols in highbush blueberries are phenolic acids, flavonols, anthocyanins and procyanidins [Krupa and Tomala 2007, Łata et al. 2005, Barnes et al. 2009]. Due to the seasonality of highbush blueberries, it is necessary to preserve them after harvest.

Osmotic dehydration is considered a method that minimizes adverse physical and chemical changes in foodstuffs as compared to the traditional preservation techniques used in the food industry. In the process of dehydration, the material is immersed in a solution with high osmotic pressure to induce diffusive mass transfer between the solution and the biological material being dehydrated. In industrial applications, sucrose, glucose, fructose and starch syrup solutions are most often used [Torregiani and Bertolo 2001].

The main advantage of osmotic dehydration is the fact that water is removed from the product without phase change, which significantly contributes to the preservation of the appropriate quality of the material being processed. Free intercellular spaces are filled with the osmotic substance that penetrates the product. The low-molecular weight components of vacuolar sap [organic acids, mineral salts, vitamins, phenolic compounds) may leak to the osmotic solution. Thus, the process conditions should be optimized so as to reduce the loss of valuable nutrients from fruits [Lewicki and Lenart 2006].

A factor that hampers a wider application of the discussed method is a lack of efficient ways of utilizing spent osmotic solutions. The high concentration of carbohydrates, the presence of remains of the dehydrated material, as well as the proliferation of microorganisms make such solutions difficult to reuse. Due to the high costs of purification, spent osmotic solutions are considered an industrial waste. However, as a result of the presence of valuable nutrients leaked from fruits, as well as owing to economic and environmental considerations, scientists seek ways in which at least some of these solutions could be utilized [Dalla Rosa and Giroux 2001]. The suggestion most often made in the literature is to reuse the osmotic solution in successive cycles of the process. In a study by Valdez-Fragoso et al. [2002], osmotic dehydration of apples with a $60^{\circ} \mathrm{Bx}$ sucrose solution reused for 20 cycles was carried out without a significant increase in dry matter content or water loss in consecutive batches of dehydrated fruits. Uczciwek et al. [2011] have shown that one can reuse a fructooligosaccharide concentrate multiple times for dehydration of sour cherries, blackcurrants and apples.

Alternatively, spent osmotic solutions may be utilized in the production of other foodstuffs. For example, Garcia et al. [2009] recycled a sucrose solution that had been used in osmo-convective drying of mangoes as a material for wine production. According to consumers, the product was acceptable and did not differ much from commercial wines. Alternatively, spent osmotic solution may also be used as an ingredient in jams and a raw material in the production of fruit juices and natural aromas [Dalla Rosa and Giroux 2001]. Sucrose osmotic solutions may also be converted into fructooligosacharide concentrates [Aachary and Prapulla 2009].

An important aspect of the utilization of spent osmotic solutions is microbiological contamination. Syrup microflora reflects both primary and secondary contamination, originating from the raw material and from the production process, respectively. According to literature data, spent solutions particularly susceptible to the proliferation of undesirable microorganisms are those used for the dehydration of vegetables. Solutions used for fruit dehydration are less vulnerable as their $\mathrm{pH}$ is usually acidic. In the literature there are no straightforward guidelines as to permissible contamination levels for spent osmotic solutions. Nevertheless, thermal treatment is proposed in order to eliminate the risks posed by excessive microbial contamination. For instance, in one study mild pasteurization $\left(71-75^{\circ} \mathrm{C}\right.$ for $30 \mathrm{~s}$ ) reduced mold levels to $1 \mathrm{CFU} / \mathrm{mL}$ and bacteria levels to $10^{2} \mathrm{CFU} / \mathrm{mL}$ (from $10^{5}$ ) [Dalla Rosa and Giroux 2001].

However, thermal treatment may lead to a reduction in the content in biologically active substances, including polyphenols, anthocyanins, phenolic acids and other important compounds, such as vitamin C. 
Therefore, we sought methods that would ensure adequate microbiological purity of the syrup while retaining its desirable components.

The objective of the work was to study the influence of thermal treatment on the content of phenolic compounds and on the degradation of the microflora contaminating sucrose syrups following 15 cycles of osmotic dehydration of highbush blueberry (Vaccinium corymbosum L.) fruits.

\section{MATERIAL AND METHODS}

\section{Material}

The tested material was sucrose solution used for 15 cycles of osmotic dehydration of highbush blueberry (Vaccinium corymbosum L., cultivar Bluecrop) fruits. The fruits were purchased from a grower in Łódź Province (Poland) at the beginning of August 2012, and then stored at $-20^{\circ} \mathrm{C}$.

\section{Pretreatment of fruits prior to osmotic dehydration}

First, $200 \pm 1 \mathrm{~g}$ of the fruits (kept at approx. $22^{\circ} \mathrm{C}$ for 20 min after taking out from a freezer) was weighed into a beaker, and then $800 \mathrm{~mL}$ of water was added. The water (with fruits) was brought to $\mathrm{pH} 6.5 \pm 0.5$ with $0.1 \mathrm{M} \mathrm{NaOH}$. Subsequently, $0.075 \mathrm{~mL}$ of Palatase $750-\mathrm{L}$ preparation containing lipase (Novozymes A/S, Bagsvaerd, Denmark) with an enzyme activity of 750 PGU/mL was added, and the beaker was left to stand for $30 \mathrm{~min}$ at room temperature. Next, the fruits were separated from the solution and washed with water three times. Subsequently, the fruits (after mixing with $800 \mathrm{~mL}$ of water; $\mathrm{pH}=4.2 \pm 0.2, t=25 \pm 2^{\circ} \mathrm{C}$ ) were treated with pectinase using $1.35 \mathrm{~mL}$ of Pectinex Yield Mash preparation (Novozymes, Bagsvaerd, Denmark) with an enzyme activity of $46.000 \mathrm{PGU} / \mathrm{mL}$ (30 min at room temperature). Next, the fruits were separated from the solution and washed with water three times.

\section{Osmotic dehydration}

Following enzymatic pretreatment, $200 \pm 2 \mathrm{~g}$ fruit samples were weighed into plastic containers. The dehydration process was conducted using $65^{\circ} \mathrm{Bx}$ sucrose solution at $40^{\circ} \mathrm{C}$ for $2 \mathrm{~h}$ with continuous vortexing (200 cycles/min). The fruit to syrup ratio was 1:4 (w/w). Following osmotic dehydration, the fruits were drained on a sieve (rinsed with distilled water, and dried with filter paper). The syrup was reused for subsequent 14 cycles of osmotic dehydration. For each cycle, the concentration of the solution was adjusted by adding $70 \pm 5^{\circ} \mathrm{Bx}$ sucrose solution. A new batch of fruits was dehydrated each time.

\section{Thermal treatment of osmotic solution}

The experiments involved thermal treatment with the use of glass capillaries with the following dimensions: an external diameter of $d_{\mathrm{ex}}=1.4 \mathrm{~mm}$, an internal diameter of $d_{\text {in }}=0.8 \mathrm{~mm}$, and a length of $20 \mathrm{~cm}$. The capillaries were filled with sucrose solution after 15 cycles of osmotic dehydration, diluted to 15 $\pm 0.5^{\circ} \mathrm{Bx}$ with sterile distilled water. Each capillary contained $0.05 \mathrm{~mL}$ of solution, which amounted to approx $50 \%$ of the capillary volume. The capillaries filled in this way were sealed with the flame of a gas burner and placed in a Teflon holder made especially for that purpose. The holder was used to immerse the capillaries in an oil bath (TU-20D from Techne). Every capillary was heated with oil at a desired constant temperature: $70,80,90,100$ or $115^{\circ} \mathrm{C}$ for 20,40 or $60 \mathrm{~s}$. Following the thermal treatment, the capillaries were immediately cooled in a water bath. Subsequently, the solution was removed and subjected to microbiological analyses and tested for polyphenols.

\section{Microbiological analyses}

a. Total mesophilic bacteria count-by the pour plate method with PCA medium-incubation at $30^{\circ} \mathrm{C}$ for up to 3 days.

b. Determination of (osmotolerant) yeasts/molds-by the pour plate method with Whaley Scar mediumincubation at $30^{\circ} \mathrm{C}$ for up to 5 days.

c. Total thermophilic bacteria count-by the pour plate method with Cameron medium-incubation at $55^{\circ} \mathrm{C}$ for up to 2 days.

In the experiments, syrup samples were poured directly onto plates in two replicates for every determination. After incubation, the resulting colonies were counted and the results were given as $\mathrm{CFU} / \mathrm{mL}$ of the analysed syrup solution.

\section{Determination of total polyphenols content}

First, $0.5 \mathrm{~mL}$ of the sample, $0.25 \mathrm{~mL}$ of FolinCiocalteu reagent, and $2.5 \mathrm{~mL}$ of $20 \% \mathrm{Na}_{2} \mathrm{CO}_{3}$ were 
Kucner A., Papiewska A., Klewicki R., Sójka M., Klewicka E., 2014. Influence of thermal treatment on the stability of phenolic compounds and the microbiological quality of sucrose solution following osmotic dehydration of highbush blueberry fruits. Acta Sci. Pol., Technol. Aliment. 13(1), 79-88.

placed in $25 \mathrm{~mL}$ volumetric flasks. Then, the flasks were filled with distilled water and the contents were mixed and incubated at room temperature for $1 \mathrm{~h}$. The absorbance of the solutions was measured at $720 \mathrm{~nm}$. Total polyphenols content was expressed as (-)-epicatechin equivalents [Singleton and Rossi 1965].

\section{Determination of anthocyanin content with the HPLC method}

Chromatographic analysis was performed using a Knauer HPLC chromatograph with $5 \mathrm{uC} 18110$ A Phenomenex Gemini columns $(150 \times 4.60 \mathrm{~mm})$ and a Security Guard Phenomenex Gemini system $(4 \times 3.0$ $\mathrm{mm})$. Separation was performed at $40^{\circ} \mathrm{C}$, the flow rate was $1 \mathrm{~mL} / \mathrm{min}$ and a DAD detector was used. Phase A: $\mathrm{H}_{2} \mathrm{O}: \mathrm{HCOOH}(9: 1, \mathrm{v} / \mathrm{v})$, phase B: $\mathrm{ACN}: \mathrm{H}_{2} \mathrm{O}: \mathrm{HCOOH}$ 95:4:1, v/v) with the flow gradient: $12 \% \mathrm{~B}$ from 0 to $0.6 \mathrm{~min}, 12$ to $30 \% \mathrm{~B}$ from 0.6 to $16 \mathrm{~min}, 100 \% \mathrm{~B}$ from 22 to $25 \mathrm{~min}$, and $12 \% \mathrm{~B}$ from 25 to $35 \mathrm{~min}$. The injection volume was $20 \mu \mathrm{L}$. Separation was performed on solutions obtained in point "Thermal treatment of osmotic solution". The samples were diluted with mobile phase A $(1: 1(\mathrm{v} / \mathrm{v}))$ and centrifuged at $5000 \mathrm{rev} . / \mathrm{min}$ before injection. Data were collected with Eurochrom 2000 software (Knauer, Germany). Standards obtained from Extrasynthèse (Geny, France) and Sigma-Aldrich (Steinheim, Germany), MS analyses, as well as literature data [Kalt et al. 1999, Häkkinen and Torronen 2000, Wu and Prior 2005, Castrejón et al. 2008, Lohachoompol et al. 2008, You et al. 2011] were used for the identification of anthocyanins. Quantitative results of the determinations are given as cyanidin-3-glucoside equivalents.

\section{Preparation of samples for MS analysis}

Anthocyanins were separated using a Knauer HPLC chromatograph (point "Determination of anthocyanin content with the HPLC method") equipped with a fraction collector FOXY R1 (Teledyne ISCO Lincoln, NE, USA). Peaks were collected from ten repeated HPLC separations. The obtained samples were diluted 1:3 with distilled water and passed through the SPE columns (STRATA X, Phenomenex, Torrance, CA, USA) previously pre-conditioned with $1 \mathrm{~mL}$ $100 \% \mathrm{MeOH}$ and $1 \mathrm{~mL} \mathrm{H}_{2} \mathrm{O}$. The retained compounds were eluted with $1 \mathrm{~mL}$ of $100 \% \mathrm{MeOH}$.

\section{LC-ESI-MS/MS analysis}

The samples prepared according to point "Preparation of samples for MS analysis" were directly injected into MS detector (LTQ VETOS, Thermo Scientific, Waltham, MA, USA). Analyses utilized the positive ion mode. The source parameters were as follows: ion spray voltage $3.00 \mathrm{kV}$, capillary temperature $325^{\circ} \mathrm{C}$, sheath gas 30 units/min, auxiliary gas 10 units/min. To generate MS/MS data, the precursor ions were fragmented by helium gas collision in the ion trap by optimizing the collision energy in order to obtain an intensity of the precursor ion close to $10 \%$ of the relative scale of the spectrum.

\section{Determination of the content of flavanols (procyanidins and catechins) with the HPLC method}

First, syrups were dried in a Laboratory Freeze Dryer (Martin Christ Gefriertrovknungsanlagen, Osterode AM Harz, Germany). Subsequently, $20 \mathrm{mg} \pm 1.0 \mathrm{mg}$ of a sample was weighed into a $2 \mathrm{~mL}$ Eppendorf tube and $800 \mu \mathrm{L}$ of methanol solution containing phloroglucinol $(75 \mathrm{~g} / \mathrm{L})$ and ascorbic acid $(1 \mathrm{~g} / \mathrm{L})$ was added. The reaction was started by adding $400 \mu \mathrm{L} 0.4 \mathrm{M} \mathrm{HCl}$ in dry methanol. Then, the sample was mixed thoroughly and placed in a water bath at $50^{\circ} \mathrm{C}$ for $30 \mathrm{~min}$. The samples were immediately cooled in an ice bath and the reaction was stopped by adding $600 \mu \mathrm{L}$ $40 \mu \mathrm{M}$ sodium acetate solution. The samples were centrifuged for $5 \mathrm{~min}$ at $5000 \mathrm{rev} . / \mathrm{min}$, and then diluted twice with $40 \mu \mathrm{M}$ sodium acetate solution. Acid degradation products of polymeric proanthocyanidins were separated using a chromatograph from Knauer (Berlin, Germany) equipped with a UV-Vis detector and a fluorescence detector (FD). Separation of components was performed on C18 110A 5U Gemini columns $(250 \times 4.6 \mathrm{~mm})$ using a gradient of two mobile phases. Phase A: $0.25 \%(\mathrm{v} / \mathrm{v})$ formic acid in water; phase B: $80 \%(\mathrm{v} / \mathrm{v})$ acetonitrile in water. Separation was performed at a flow rate of $1 \mathrm{~mL} / \mathrm{min}$ at $25^{\circ} \mathrm{C}$ and a gradient of $4-7 \% \mathrm{~B}$ for $0-10 \mathrm{~min}, 7-30 \% \mathrm{~B}$ for 10-27 min, 30-70\% B for 27-29 min, 70\% B for $29-34$ $\mathrm{min}, 70-4 \% \mathrm{~B}$ for $34-35 \mathrm{~min}$, and $4 \% \mathrm{~B}$ for $35-40 \mathrm{~min}$. The injection volume was $20 \mu \mathrm{L}$. Data were collected with Eurochrom 2000 software (Knauer). Quantitative analysis was performed using the peak area recorded by the FD detector with the excitation wavelength set 
to $278 \mathrm{~nm}$ and the emission wavelength to $360 \mathrm{~nm}$. Quantitative calculations were based on the following calibration curves:(-)-epicatechin, (+)-catechin, and (-)-epicatechin-phloroglucinol.

\section{Statistical analysis}

The results were analysed statistically using oneway ANOVA and Duncan's multiple range test at $p<$ 0.05 with the Statistica 6.1 software (Stat Soft, Tulsa, OK, USA)

\section{RESULTS AND DISCUSSION}

\section{Microbiological analysis of syrup}

Experiments showed that thermal treatment of the sucrose solution led to a decrease in the number of microorganisms, the extent of which depended on the type of microbes and process parameters (Table 1). Total mesophilic bacteria count in untreated solution ranged from 4 to $6 \times 10^{2} \mathrm{CFU} / \mathrm{mL}$, and dropped to 3-6 $\times 10^{1} \mathrm{CFU} / \mathrm{mL}$ following heating at 70,80 and $90^{\circ} \mathrm{C}$ for 20,40 and $60 \mathrm{~s}$. Within this temperature range, it would be perhaps advisable to apply longer thermal treatment to achieve a more efficient degradation of mesophilic bacteria. If the treatment is conducted for too short a period, the bacteria may only be weakened (reversible mutations may be induced), and subsequently they may regenerate. Treatment at $100^{\circ} \mathrm{C}$ led to greater destruction of this group of microorganisms, especially at longer exposure times (after $20 \mathrm{~s}$ their survivability amounted to $1.3 \times 10^{1}$ $\mathrm{CFU} / \mathrm{mL}$, while after $60 \mathrm{~s}$ it decreased to less than $10 \mathrm{CFU} / \mathrm{mL})$. At a higher temperature $\left(115^{\circ} \mathrm{C}\right)$ and longer exposure times, the survival of mesophilic bacteria in the heated syrup solution remained at less than $10 \mathrm{CFU} / \mathrm{mL}$.

The syrup used in the experiments is susceptible to spoilage caused by yeasts and molds due to the presence of sucrose [Dalla Rosa and Giroux 2001]. Contamination with yeast and mold cells (especially those tolerating the high sugar concentrations in the starting solution) ranged from 2.5 to $4 \times 10^{1} \mathrm{CFU} / \mathrm{mL}$. According to the literature, an excessive accumulation of this kind of microflora may lead to adverse changes in the quality of food products [Dalla Rosa and Giroux 2001, Sapata et al. 2009]. The thermal treatment applied in our experiments, in all the tested temperature variants, resulted in an effective reduction of yeast and mold contamination to a level of less than $10 \mathrm{CFU} / \mathrm{mL}$, and, at 100 and $115^{\circ} \mathrm{C}$, to less than $1 \mathrm{CFU} / \mathrm{mL}$.

Table 1. Influence of thermal treatment on the survival of microorganisms present in sucrose solution following 15 cycles of osmotic dehydration

\begin{tabular}{|c|c|c|c|c|c|c|c|}
\hline \multirow{2}{*}{$\begin{array}{l}\text { Microbial group } \\
\text { CFU } / \mathrm{ml}\end{array}$} & \multirow{2}{*}{$\underset{\mathrm{s}}{\text { Time }}$} & \multirow{2}{*}{$\begin{array}{l}\text { Syrup before } \\
\text { heat treatment }\end{array}$} & \multicolumn{5}{|c|}{ Temperature, ${ }^{\circ} \mathrm{C}$} \\
\hline & & & 70 & 80 & 90 & 100 & 115 \\
\hline \multirow{3}{*}{$\begin{array}{l}\text { Total mesophilic } \\
\text { bacteria }\end{array}$} & 20 & $5 \cdot 10^{2 a}$ & $6 \cdot 10^{1 \mathrm{~b}}$ & $2 \cdot 10^{1 \mathrm{~b}}$ & $2 \cdot 10^{1 \mathrm{~b}}$ & $1.3 \cdot 10^{1 \mathrm{~b}}$ & $<10^{\mathrm{b}}$ \\
\hline & 40 & $5 \cdot 10^{2 \mathrm{a}}$ & $2 \cdot 10^{1 \mathrm{~b}}$ & $3 \cdot 10^{1 \mathrm{~b}}$ & $2 \cdot 10^{1 \mathrm{~b}}$ & $<10^{\mathrm{b}}$ & $<10^{\mathrm{b}}$ \\
\hline & 60 & $5 \cdot 10^{2 a}$ & $2 \cdot 10^{1 \mathrm{~b}}$ & $2 \cdot 10^{1 \mathrm{~b}}$ & $1.3 \cdot 10^{1 \mathrm{~b}}$ & $<10^{\mathrm{b}}$ & $<10^{\mathrm{b}}$ \\
\hline \multirow{3}{*}{$\begin{array}{l}\text { Osmotolerant yeast } \\
\text { molds }\end{array}$} & 20 & $3.5 \cdot 10^{1 \mathrm{a}}$ & $<1^{\text {b }}$ & $<1^{\text {b }}$ & $<10^{b}$ & $<10^{\mathrm{b}}$ & $<10^{\mathrm{b}}$ \\
\hline & 40 & $3.5 \cdot 10^{1 \mathrm{a}}$ & $<1^{\mathrm{b}}$ & $<1^{\text {b }}$ & $<1^{\mathrm{b}}$ & $<1^{\mathrm{b}}$ & $<10^{\mathrm{b}}$ \\
\hline & 60 & $3.5 \cdot 10^{1 \mathrm{a}}$ & $<10^{\mathrm{b}}$ & $<1^{\mathrm{b}}$ & $<10^{\mathrm{b}}$ & $<10^{\mathrm{b}}$ & $<1^{\text {b }}$ \\
\hline \multirow{3}{*}{$\begin{array}{l}\text { Total thermophilic } \\
\text { bacteria }\end{array}$} & 20 & $<1^{\mathrm{a}}$ & $<10^{\mathrm{a}}$ & $<10^{\mathrm{a}}$ & $<1^{\mathrm{a}}$ & $<1^{\mathrm{a}}$ & $<1^{\mathrm{a}}$ \\
\hline & 40 & $<1^{\mathrm{a}}$ & $<1^{\mathrm{ab}}$ & $<1^{\mathrm{a}}$ & $<10^{\mathrm{b}}$ & $<1^{\mathrm{a}}$ & $<1^{\text {a }}$ \\
\hline & 60 & $<1^{\mathrm{a}}$ & $<10^{\mathrm{ab}}$ & $<10^{\mathrm{b}}$ & $<1^{\mathrm{a}}$ & $<1^{\mathrm{a}}$ & $<1^{\mathrm{a}}$ \\
\hline
\end{tabular}

The same letter in a given line indicates a lack of statistical differences $(\alpha=0.05)$ between the results at particular processing times. 
Kucner A., Papiewska A., Klewicki R., Sójka M., Klewicka E., 2014. Influence of thermal treatment on the stability of phenolic compounds and the microbiological quality of sucrose solution following osmotic dehydration of highbush blueberry fruits. Acta Sci. Pol., Technol. Aliment. 13(1), 79-88.

\section{Influence of thermal treatment on the content of phenolic compounds}

Total polyphenols content in the starting sucrose solution following 15 cycles of dehydration was 729.2 $\pm 31.6 \mathrm{mg} / \mathrm{kg}$ IDM. This figure is relatively low as compared to the amount of polyphenols in the studied raw material, but previous research [Kucner et al. 2012] has shown that the above-mentioned conditions of osmotic dehydration are optimal from the point of view of phenolic compound retention in fruits and osmotic dehydration effectiveness.

The data given in Table 2 indicate that thermal treatment of syrups leads to a reduction in total polyphenols as compared to the control. In all the tested temperature variants, treatment time influenced the content of the studied compounds. The longer the syrup was exposed to high temperatures, the greater the losses of the compounds were. For example, after $20 \mathrm{~s}$ of heating of the solution at $90^{\circ} \mathrm{C}$, total polyphenols retention amounted to $96.1 \%$, while after $60 \mathrm{~s}$ it dropped to $87.3 \%$. The most dramatic decline in the content of the studied compounds was observed at $115^{\circ} \mathrm{C}$ : after $60 \mathrm{~s}$ total polyphenols content fell to $76.9 \%$ as compared to the starting syrup. After heating the solution at $100^{\circ} \mathrm{C}$, total polyphenols retention $(94.5 \%$ to $77.9 \%)$ was similar to that obtained at $80^{\circ} \mathrm{C}(97.8 \%$ to $77.9 \%$ ). Numerous studies have shown that the main factors reducing polyphenols content in fruits during processing are temperature and process time. For instance, Klopotek et al. [2005] reported a 27.3\% loss of polyphenols following 5 min pasteurization of strawberry juice at $85^{\circ} \mathrm{C}$. Blanching of highbush blueberry fruits at $95^{\circ} \mathrm{C}$ for $2 \mathrm{~min}$ led to a total polyphenols loss of about 10\% [Ścibisz and Mitek 2006]. Thus, the results obtained in our tests are similar to literature data.

A detailed phenolic profile of the highbush blueberry fruits used in the process of osmotic dehydration is given in Table 3.

Our experiments show that not all anthocyanins present in the fruits migrated to the syrup. Among all the anthocyanins identified in the syrup, malvidin derivatives were the most abundant $(62.9 \%)$. The osmotic solution was found to have a relatively high content of chlorogenic acid, at a concentration of 108.6 $\pm 4.6 \mathrm{mg} / \mathrm{kg}$ IDM. Similarly as in the case of total polyphenols content, there exists a relationship between the process temperature and time and the content of these compounds. Heating led to gradual degradation of phenolic compounds. At temperatures ranging from 70 to $115^{\circ} \mathrm{C}$, chlorogenic acid content declined slightly, by up to $7 \%$. However, after $60 \mathrm{~s}$, the content of this compound was halved. This was also the case with particular anthocyanin compounds. The smallest anthocyanin losses were recorded in samples exposed to thermal treatment at $70^{\circ} \mathrm{C}$ and for $20 \mathrm{~s}(98.8 \%$ to $97.5 \%$ retention). The compound most vulnerable to heating was a derivative of malvidin and pentose (its exact structure was not determined), whose retention after $60 \mathrm{~s}$ was $24.8 \%$ and $8.2 \%$ at $90^{\circ} \mathrm{C}$ and $100^{\circ} \mathrm{C}$, respectively. Much greater stability was revealed by a compound described as malvidin + acetoyl + hexose (1). Following $40 \mathrm{~s}$ of thermal treatment at $70^{\circ} \mathrm{C}$ its retention amounted to $75.3 \%$, while at $115^{\circ} \mathrm{C}$ it was $65.5 \%$. These results are in agreement with the observations

Table 2. Influence of thermal treatment on total polyphenols content in syrup following 15 dehydration cycles, $\mathrm{mg} / \mathrm{kg}$ IDM

\begin{tabular}{ccccccc}
\hline \multirow{2}{*}{$\begin{array}{c}\text { Time } \\
\mathrm{s}\end{array}$} & $\begin{array}{c}\text { Syrup before heat } \\
\text { treatment } \\
\mathrm{mg} / \mathrm{kg} \text { IDM }\end{array}$ & 70 & 80 & 90 & 100 & 115 \\
\cline { 3 - 7 } & $729.2 \pm 31.6^{\mathrm{a}}$ & $667.7 \pm 7.9^{\mathrm{b}}$ & $712.4 \pm 23.7^{\mathrm{ab}}$ & $636.7 \pm 4.3^{\mathrm{c}}$ & $655.5 \pm 31.8^{\mathrm{bc}}$ & $656.0 \pm 41.2^{\mathrm{abc}}$ \\
\hline 20 & $729.2 \pm 31.6^{\mathrm{a}}$ & $650.9 \pm 43.3^{\mathrm{ab}}$ & $708.8 \pm 4.1^{\mathrm{ab}}$ & $700.5 \pm 45.4^{\mathrm{ab}}$ & $688.7 \pm 0.7^{\mathrm{ab}}$ & $608.4 \pm 13.5^{\mathrm{b}}$ \\
40 & $729.2 \pm 31.6^{\mathrm{a}}$ & $595.0 \pm 15.8^{\mathrm{c}}$ & $567.9 \pm 6.7^{\mathrm{c}}$ & $667.8 \pm 23.6^{\mathrm{b}}$ & $567.8 \pm 3.2^{\mathrm{c}}$ & $561.1 \pm 8.0^{\mathrm{c}}$ \\
\hline 60 & &
\end{tabular}

The same letter in a given line indicates a lack of statistical differences $(\alpha=0.05)$ between the results at particular processing times. 
Kucner A., Papiewska A., Klewicki R., Sójka M., Klewicka E., 2014. Influence of thermal treatment on the stability of phenolic compounds and the microbiological quality of sucrose solution following osmotic dehydration of highbush blueberry fruits. Acta Sci. Pol., Technol. Aliment. 13(1), 79-88.

Table 3. Influence of thermal treatment on the content of selected polyphenols in syrup following 15 dehydration cycles, $\mathrm{mg} / \mathrm{kg}$ IDM

\begin{tabular}{|c|c|c|c|c|c|c|}
\hline \multirow{2}{*}{ Compound } & \multirow{2}{*}{$\begin{array}{l}\text { Syrup before } \\
\text { heat treatment }\end{array}$} & \multicolumn{5}{|c|}{ Temperature, ${ }^{\circ} \mathrm{C}$} \\
\hline & & 70 & 80 & 90 & 100 & 115 \\
\hline \multicolumn{7}{|l|}{ Time $20 \mathrm{~s}$} \\
\hline Chlorogenic acid & $108.57 \pm 4.59^{\mathrm{a}}$ & $105.94 \pm 1.48^{\mathrm{a}}$ & $101.22 \pm 0.44^{\mathrm{a}}$ & $103.12 \pm 5.52^{\mathrm{a}}$ & $104.21 \pm 6.48^{\mathrm{a}}$ & $104.31 \pm 1.23^{\mathrm{a}}$ \\
\hline Cyanidin-3-O-galacyoside & $1.60 \pm 0.07^{\mathrm{a}}$ & $1.58 \pm 0.06^{\mathrm{a}}$ & $1.59 \pm 0.04^{\mathrm{a}}$ & $1.51 \pm 0.06^{\mathrm{a}}$ & $1.55 \pm 0.07^{\mathrm{a}}$ & $1.49 \pm 0.02^{\mathrm{a}}$ \\
\hline Malvidin-3-O-glucoside & $28.11 \pm 0.78^{\mathrm{a}}$ & $27.77 \pm 0.26^{\mathrm{a}}$ & $25.03 \pm 0.02^{\mathrm{b}}$ & $24.96 \pm 2.12^{\mathrm{b}}$ & $26.88 \pm 2.07^{\mathrm{ab}}$ & $26.38 \pm 0.20^{\mathrm{ab}}$ \\
\hline Malvidin-3-O-arabinoside & $14.09 \pm 0.45^{\mathrm{a}}$ & $13.78 \pm 0.03^{\mathrm{a}}$ & $13.34 \pm 0.19^{\mathrm{ab}}$ & $13.53 \pm 0.74^{\mathrm{a}}$ & $13.19 \pm 1.98^{\mathrm{ab}}$ & $12.77 \pm 0.41^{\mathrm{b}}$ \\
\hline NI & $22.94 \pm 0.69^{\mathrm{a}}$ & $22.48 \pm 0.11^{\mathrm{a}}$ & $17.76 \pm 0.41^{\mathrm{b}}$ & $18.05 \pm 0.82^{b}$ & $20.51 \pm 2.46^{\mathrm{ab}}$ & $19.99 \pm 0.61^{\mathrm{ab}}$ \\
\hline Malvidin + pentose & $0.80 \pm 0.05^{\mathrm{a}}$ & $0.79 \pm 0.01^{\mathrm{a}}$ & $0.66 \pm 0.06^{\mathrm{b}}$ & $0.70 \pm 0.06^{\mathrm{b}}$ & $0.72 \pm 0.02^{\mathrm{b}}$ & $0.68 \pm 0.02^{\mathrm{b}}$ \\
\hline Malvidin + acetoyl + hexose (I) & $0.12 \pm 0.03^{\mathrm{a}}$ & $0.11 \pm 0.03^{\mathrm{a}}$ & $0.08 \pm 0.02^{\mathrm{a}}$ & $0.09 \pm 0.02^{\mathrm{a}}$ & $0.11 \pm 0.01^{\mathrm{a}}$ & $0.06 \pm 0.01^{\mathrm{b}}$ \\
\hline Malvidin + acetoyl + hexose (II) & $0.65 \pm 0.09^{\mathrm{a}}$ & $0.61 \pm 0.01^{\mathrm{a}}$ & $0.57 \pm 0.17^{\mathrm{a}}$ & $0.64 \pm 0.07^{\mathrm{a}}$ & $0.61 \pm 0.06^{\mathrm{a}}$ & $0.59 \pm 0.00^{\mathrm{a}}$ \\
\hline Malvidin + acetoyl + hexose (III) & $2.85 \pm 0.09^{\mathrm{a}}$ & $2.78 \pm 0.12^{\mathrm{a}}$ & $2.64 \pm 0.04^{\mathrm{b}}$ & $2.70 \pm 0.13^{\mathrm{a}}$ & $2.58 \pm 0.34^{\mathrm{b}}$ & $2.50 \pm 0.08^{b}$ \\
\hline \multicolumn{7}{|l|}{ Time $40 \mathrm{~s}$} \\
\hline Chlorogenic acid & $108.57 \pm 4.59^{\mathrm{a}}$ & $94.12 \pm 3.61^{\mathrm{b}}$ & $81.35 \pm 9.39^{b}$ & $81.37 \pm 9.63^{b}$ & $62.96 \pm 3.38^{c}$ & $54.11 \pm 5.44^{c}$ \\
\hline Cyanidin-3-O-galacyoside & $1.60 \pm 0.07^{\mathrm{a}}$ & $1.17 \pm 0.02^{\mathrm{b}}$ & $1.24 \pm 0.20^{\mathrm{b}}$ & $1.57 \pm 0.34^{\mathrm{a}}$ & $1.15 \pm 0.38^{\mathrm{b}}$ & $0.81 \pm 0.30^{\mathrm{b}}$ \\
\hline Malvidin-3-O-glucoside & $28.11 \pm 0.78^{\mathrm{a}}$ & $21.69 \pm 0.61^{\mathrm{b}}$ & $16.76 \pm 2.27^{\mathrm{c}}$ & $17.22 \pm 2.50^{\mathrm{cd}}$ & $10.66 \pm 2.53^{\mathrm{d}}$ & $6.51 \pm 1.74^{\mathrm{e}}$ \\
\hline Malvidin-3-O-arabinoside & $14.09 \pm 0.45^{\mathrm{a}}$ & $10.96 \pm 0.41^{\mathrm{b}}$ & $8.78 \pm 0.80^{\mathrm{c}}$ & $9.54 \pm 1.02^{\mathrm{c}}$ & $6.06 \pm 0.21^{\mathrm{d}}$ & $4.14 \pm 0.52^{\mathrm{e}}$ \\
\hline NI & $22.94 \pm 0.69^{\mathrm{a}}$ & $17.31 \pm 0.59^{\mathrm{b}}$ & $13.07 \pm 1.98^{c}$ & $12.42 \pm 6.07^{\mathrm{c}}$ & $7.40 \pm 0.16^{\mathrm{d}}$ & $5.09 \pm 0.14^{\mathrm{e}}$ \\
\hline Malvidin + pentose & $0.80 \pm 0.05^{\mathrm{a}}$ & $0.62 \pm 0.11^{\mathrm{b}}$ & $0.43 \pm 0.04^{\mathrm{c}}$ & $0.50 \pm 0.03^{\mathrm{c}}$ & $0.29 \pm 0.09^{\mathrm{d}}$ & $0.16 \pm 0.00^{\mathrm{e}}$ \\
\hline Malvidin + acetoyl + hexose (I) & $0.12 \pm 0.03^{\mathrm{a}}$ & $0.09 \pm 0.01^{\mathrm{a}}$ & $0.08 \pm 0.04^{\mathrm{a}}$ & $0.04 \pm 0.00^{\mathrm{b}}$ & $0.10 \pm 0.00^{\mathrm{a}}$ & $0.08 \pm 0.02^{\mathrm{a}}$ \\
\hline Malvidin + acetoyl + hexose (II) & $0.65 \pm 0.09^{\mathrm{a}}$ & $0.60 \pm 0.04^{\mathrm{a}}$ & $0.52 \pm 0.05^{\mathrm{a}}$ & $0.51 \pm 0.04^{\mathrm{a}}$ & $0.57 \pm 0.04^{\mathrm{a}}$ & $0.54 \pm 0.07^{\mathrm{a}}$ \\
\hline Malvidin + acetoyl + hexose (III) & $2.85 \pm 0.09^{\mathrm{a}}$ & $2.18 \pm 0.02^{\mathrm{b}}$ & $1.83 \pm 0.08^{c}$ & $1.87 \pm 0.09^{\mathrm{c}}$ & $1.25 \pm 0.06^{\mathrm{d}}$ & $0.86 \pm 0.06^{\mathrm{e}}$ \\
\hline \multicolumn{7}{|l|}{ Time $60 \mathrm{~s}$} \\
\hline Chlorogenic acid & $108.57 \pm 4.59^{\mathrm{a}}$ & $60.37 \pm 0.64^{\mathrm{c}}$ & $74.65 \pm 0.10^{\mathrm{b}}$ & $65.14 \pm 6.61^{\mathrm{bc}}$ & $52.44 \pm 2.64^{\mathrm{d}}$ & $54.14 \pm 0.55^{\mathrm{d}}$ \\
\hline Cyanidin-3-O-galacyoside & $1.60 \pm 0.07^{\mathrm{a}}$ & $1.04 \pm 0.08^{\mathrm{b}}$ & $1.33 \pm 0.08^{c}$ & $0.86 \pm 0.08^{\mathrm{d}}$ & $0.91 \pm 0.05^{\mathrm{b}}$ & $1.23 \pm 0.05^{\mathrm{c}}$ \\
\hline Malvidin-3-O-glucoside & $28.11 \pm 0.78^{\mathrm{a}}$ & $10.16 \pm 0.04^{c}$ & $15.16 \pm 0.02^{\mathrm{b}}$ & $11.13 \pm 1.28^{\mathrm{c}}$ & $7.11 \pm 0.53^{\mathrm{d}}$ & $6.96 \pm 0.30^{\mathrm{d}}$ \\
\hline Malvidin-3-O-arabinoside & $14.09 \pm 0.45^{\mathrm{a}}$ & $5.61 \pm 0.02^{\mathrm{c}}$ & $8.23 \pm 0.01^{\mathrm{b}}$ & $5.80 \pm 0.63^{\mathrm{c}}$ & $3.27 \pm 0.33^{\mathrm{d}}$ & $3.08 \pm 0.23^{\mathrm{d}}$ \\
\hline NI & $22.94 \pm 0.69^{\mathrm{a}}$ & $7.51 \pm 0.09^{\mathrm{c}}$ & $11.64 \pm 0.05^{\mathrm{b}}$ & $8.42 \pm 1.08^{c}$ & $4.51 \pm 0.31^{\mathrm{d}}$ & $4.24 \pm 0.29^{\mathrm{d}}$ \\
\hline Malvidin + pentose & $0.80 \pm 0.05^{\mathrm{a}}$ & $0.29 \pm 0.06^{\mathrm{c}}$ & $0.41 \pm 0.06^{\mathrm{b}}$ & $0.20 \pm 0.00^{\mathrm{d}}$ & $0.17 \pm 0.00^{\mathrm{d}}$ & $0.22 \pm 0.09^{\text {cd }}$ \\
\hline Malvidin + acetoyl + hexose (I) & $0.12 \pm 0.03^{\mathrm{a}}$ & $0.07 \pm 0.01^{\mathrm{b}}$ & $0.09 \pm 0.01^{\mathrm{a}}$ & $0.06 \pm 0.01^{\mathrm{a}}$ & $0.06 \pm 0.01^{\mathrm{b}}$ & $0.06 \pm 0.03^{\mathrm{b}}$ \\
\hline Malvidin + acetoyl + hexose (II) & $0.65 \pm 0.09^{\mathrm{a}}$ & $0.59 \pm 0.06^{\mathrm{a}}$ & $0.50 \pm 0.07^{\mathrm{a}}$ & $0.57 \pm 0.13^{\mathrm{a}}$ & $0.55 \pm 0.04^{\mathrm{a}}$ & $0.55 \pm 0.06^{\mathrm{a}}$ \\
\hline Malvidin + acetoyl + hexose (III) & $2.85 \pm 0.09^{\mathrm{a}}$ & $1.15 \pm 0.02^{\mathrm{c}}$ & $1.75 \pm 0.02^{\mathrm{b}}$ & $1.15 \pm 0.12^{\mathrm{c}}$ & $0.75 \pm 0.07^{\mathrm{d}}$ & $0.77 \pm 0.06^{\mathrm{d}}$ \\
\hline
\end{tabular}

NI - not identified.

The same letter in a given line indicates a lack of statistical differences $(\alpha=0.05)$. 
Kucner A., Papiewska A., Klewicki R., Sójka M., Klewicka E., 2014. Influence of thermal treatment on the stability of phenolic compounds and the microbiological quality of sucrose solution following osmotic dehydration of highbush blueberry fruits. Acta Sci. Pol., Technol. Aliment. 13(1), 79-88.

Table 4. Influence of thermal treatment on the content of flavan-3-ols in syrup following 15 dehydration cycles, $\mathrm{mg} / \mathrm{kg}$ IDM

\begin{tabular}{|c|c|c|c|c|c|c|}
\hline \multirow{2}{*}{$\begin{array}{c}\text { Time } \\
\mathrm{s}\end{array}$} & \multirow{2}{*}{$\begin{array}{c}\text { Syrup before heat } \\
\text { treatment } \\
\mathrm{mg} / \mathrm{kg} \mathrm{IDM}\end{array}$} & \multicolumn{5}{|c|}{ Temperature, ${ }^{\circ} \mathrm{C}$} \\
\hline & & 70 & 80 & 90 & 100 & 115 \\
\hline 20 & $66.6 \pm 1.4^{\mathrm{a}}$ & $56.7 \pm 1.7^{b}$ & $49.6 \pm 0.6^{c}$ & $54.2 \pm 2.3^{b}$ & $62.2 \pm 0.4^{\mathrm{a}}$ & $55.2 \pm 4.0^{\mathrm{b}}$ \\
\hline 40 & $66.6 \pm 1.4^{\mathrm{a}}$ & $51.5 \pm 2.6^{\mathrm{bc}}$ & $46.9 \pm 1.0^{\mathrm{cd}}$ & $44.2 \pm 1.9^{\mathrm{cd}}$ & $59.6 \pm 1.1^{\mathrm{ab}}$ & $36.7 \pm 3.4^{\mathrm{d}}$ \\
\hline 60 & $66.6 \pm 1.4^{\mathrm{a}}$ & $44.4 \pm 3.8^{b}$ & $44.4 \pm 1.3^{b}$ & $41.2 \pm 0.5^{\mathrm{b}}$ & $24.9 \pm 4.9^{\mathrm{c}}$ & $27.6 \pm 0.8^{c}$ \\
\hline
\end{tabular}

The same letter in a given line indicates a lack of statistical differences $(\alpha=0.05)$ between the results at particular processing times.

made by Ścibisz et al. [2010], who showed that among the anthocyanins present in highbush blueberry fruitsthose containing galactose or glucose (hexoses) were more resistant to $40 \mathrm{~min}$ treatment at $95^{\circ} \mathrm{C}$ than those containing arabinose (a pentose).

Anthocyanins are labile compounds that are not very resistant to the action of high temperatures. Brownmiller et al. [2008] reported anthocyanin losses of $43 \%$ during the production of highbush blueberry paste ( 3 min blanching at $95^{\circ} \mathrm{C}$ ).

According to literature data, under the influence of heat glycosidic bonds in dye molecules undergo hydrolysis leading to unstable aglycones, which easily oxidize forming brown, high molecular weight compounds [Ścibisz et al. 2010].

Furthermore, the influence of thermal treatment on the content of flavan-3-ols in spent osmotic syrup was analyzed. Prior to treatment, the amount of flavan3 -ols in the syrup was $66.1 \pm 1.4 \mathrm{mg} / 100 \mathrm{~g}$ IDM. The most dramatic drop in the content of these compounds was caused by $60 \mathrm{~s}$ heating at $115^{\circ} \mathrm{C}(41.5 \%$ retention). Their degradation was the smallest after $20 \mathrm{~s}$ of thermal treatment (over $80 \%$ retention).

Analysis of the results obtained for the influence of thermal treatment on microbial destruction and the stability of phenolic compounds shows that the optimal variant is heating the syrup at $100^{\circ} \mathrm{C}$ for $40 \mathrm{~s}$. Such parameters enable the elimination of the vast majority of microorganisms with relatively low losses of phenolic compounds. As can be seen from Table 1, thermal treatment of the syrup at 70,80 and $90^{\circ} \mathrm{C}$ does not inactivate the syrup microflora as effectively as that conducted at $100^{\circ} \mathrm{C}$ or more. Heating the syrup at $100^{\circ} \mathrm{C}$ for $40 \mathrm{~s}$ results in a total polyphenols retention of $94.5 \%$; the retention of particular phenolic compounds ranges from $89.2 \%$ to $37.2 \%$, while that of flavan-3-ols is $89.5 \%$. These figures are higher than those obtained during thermal treatment of the syrup at $70^{\circ} \mathrm{C}$ for $60 \mathrm{~s}$ (the corresponding results were $81.6 \%$, from 91.4 to $32.7 \%$ and $66.6 \%$ ).

\section{CONCLUSIONS}

The present study revealed considerable variation in the content of phenolic compounds depending on the parameters of thermal treatment. Irrespective of the temperature used, after $20 \mathrm{~s}$ of treatment total polyphenols content did not change significantly ( $91.5 \%$ to $87.3 \%$ retention). Particularly sensitive to high temperatures were anthocyanin dyes and flavan3 -ols, and the content of these compounds gradually declined during heating of spent osmotic solution. The most dramatic degradation of these compounds was observed at $115^{\circ} \mathrm{C}$ after $60 \mathrm{~s}$ of thermal treatment: $78.2 \%$ of anthocyanins and $58.5 \%$ of flavan-3-ols were lost. Thermal treatment at temperatures ranging from 70 to $90^{\circ} \mathrm{C}$ did not reduce microbiological contamination as effectively as heating at 100 and $115^{\circ} \mathrm{C}$ (for $40 \mathrm{~s}$ ). From the point of view of both the microbiological quality of the syrup and the stability of the studied phenolic compounds, the optimal treatment was heating at $100^{\circ} \mathrm{C}$ for $40 \mathrm{~s}$. Total polyphenols retention amounted to $94.5 \%$; that of particular phenolic compounds ranged from $89.2 \%$ to $37.2 \%$, and that of procyanidins was $89.5 \%$. Such process parameters made it possible to achieve considerable biological 
Kucner A., Papiewska A., Klewicki R., Sójka M., Klewicka E., 2014. Influence of thermal treatment on the stability of phenolic compounds and the microbiological quality of sucrose solution following osmotic dehydration of highbush blueberry fruits. Acta Sci. Pol., Technol. Aliment. 13(1), 79-88.

purity-less than $10 \mathrm{CFU} / \mathrm{mL}$ for mesophilic bacteria and less than $1 \mathrm{CFU} / \mathrm{mL}$ for yeasts and molds.

\section{REFERENCES}

Aachary A.A., Prapulla S.G., 2009. Value addition to spent osmotic sugar (SOS) by enzymatic conversion to fructooligosaccharides (FOS), a low calorie prebiotic. Innov. Food Sci. Emerging. Technol. 10, 284-288.

Barnes J.S., Nguyen H.P., Shen S., Schug K.A., 2009. General method for extraction of blueberry anthocyanins and identification using high performance liquid chromatography-electrospray ionization-ion trap-time of flight-mass spektrometry. J. Chromatogr. A, 1216, 4728-4735.

Brownmiller C., Howard L.R., Prior R.L., 2008. Processing and storage effects on monomeric anthocyanins, percent polymeric color, and antioxidant capacity of processed blueberry products. J. Food Sci. 73, H72-H79.

Castrejón A.D.R., Eichholz I., Rohn S., Kroh L.W., Huyskens-Keil S., 2008. Phenolic profile and antioxidant activity of highbush blueberry (Vaccinium corymbosum L.) during fruit maturation and ripening. Food. Chem. 109, 564-572.

Dalla Rosa M.D., Giroux F., 2001. Osmotic treatments (OT) and problems related to the solution management. J. Food Eng. 49, 223-236.

Garcia A.S., Park J.H., Jeong H.J., Park Y.M., Chung K.M., Lee J.H., 2009. Wine production using osmotic solution from dried mango process. Food Eng. Progress 13, 130-137.

Häkkinen S.H., Torronen A.R., 2000. Content of flavonols and selected phenolic acids in strawberries and $\mathrm{Vac}$ cinium species: influence of cultivar, cultivation site and technique. Food Res. Int. 33, 517-524.

Kalt W., McDonald J.E., Ricker R.D., Lu X., 1999. Anthocyanin content and profile within and among blueberry species. Can. J. Plant Sci. 79, 617-623.

Klopotek Y., Otto K., Bhm V., 2005. Processing strawberries to different products alters contents of vitamin $\mathrm{C}$, total phenolics, total anthocyanins, and antioxidant capa city. J. Agric. Food Chem. 53, 5640-5646.

Krupa T., Tomala K., 2007. Antioxidant capacity, anthocyanin content profile in 'Bluecrop' blueberry fruit. Veg. Crops Res. Bull. 66, 129-141.

Kucner A., Klewicki R., Sójka M., 2012. The influence of selected osmotic dehydration and pretreatment parameters on dry matter and polyphenols content in highbush blueberry (Vaccinium corymbosum L.) fruits. Food Bioproc. Technol. 6, 2031-2047.

Lohachoompol V., Mulholland M., Srzednicki G., Craske J., 2008. Determination of anthocyanins in various cultivars of highbush and rabbiteye blueberries. Food Chem. 111, 249-254.

Lewicki P.P., Lenart A., 2006. Osmotic dehydration of fruits and vegetables. In: Handbook of industrial drying-3. Ed. A.S. Mujumdar. Taylor and Francis, 665-688.

Łata B., Trąpczyńska A., Mike A., 2005. Effect of cultivar and harvest date on thiols, ascorbate and phenolic compounds content in blueberries. Acta Sci. Pol., Hort. Cult. 4, 163-171.

Petti S., Scully C., 2009. Polyphenols, oral health and disease: a review. J. Dent. 37, 413-423.

Sapata M.L., Ferreira A., Andrada L., Leitão A.E., Candeias M., 2009. Osmotic dehydration of mandarins: Influence of reutilized osmotic agent on behaviour and product quality. Acta Sci. Pol., Technol. Aliment. 8, 23-35.

Singleton V.L., Rossi J.A., 1965. Colorimetry of total phenolics with phosphomolybolic - phosphotungstic acid reagents. Am. J. Enol. Vitic. 16, 144-158.

Ścibisz I., Mitek M., 2006. Antioxidant activity and phenolics compound capacity in dried highbush blueberries (Vaccinium corymbosum L.). Żywn. Technol. Jakość 46, 68-76.

Ścibisz I., Kalisz S., Mitek M., 2010. Thermal degradation of anthocyanins in blueberry fruit. Żywn. Technol. Jakość 72, 56-66.

Torreggiani D., Bertolo G., 2001. Osmotic pre-treatments in fruit processing: chemical, physical, and structural effects. J. Food Eng. 49, 247-253.

Uczciwek M., Piasecka E., Klewicki R., Konopacka D., Mieszczakowska-Frąc M., Bonazzi C., 2011. Content of selected nutrients in sour cherries, blackcurrants and apples osmodehydrated in reused fructooligosaccharide concentrate. Ital. J. Food Sci. 23, 270-278.

Wu X., Prior R.L., 2005. Systematic identification and characterization of anthocyanins by HPLC-ESI-MS/MS in common foods in the United States: fruits and berries. J. Agric. Food Chem. 53, 2589-2599.

Valdez-Fragoso A., Mujica-Paz H., Giroux F., Welti-Chanes J., 2002. Reuse of sucrose syrup in pilot-scale osmotic dehydration of apple cubes. J. Food Proc. Eng. 25, 125-139.

You Q., Wang B., Chen F., Huang Z., Wang X., Luo P.G., 2011. Comparison of anthocyanins and phenolics in organically and conventionally grown blueberries in selected cultivars. Food Chem. 125, 201-208. 


\section{WPŁYW OBRÓBKI TERMICZNEJ NA STABILNOŚĆ ZWIĄZKÓW FENOLOWYCH I JAKOŚĆ MIKROBIOLOGICZNA ROZTWORU SACHAROZY PO ODWADNIANIU OSMOTYCZNYM OWOCÓW BORÓWKI WYSOKIEJ}

\section{STRESZCZENIE}

Wstęp. Odwadnianie osmotyczne to proces prowadzący do częściowego zmniejszenia zawartości wody, który jest realizowany poprzez zanurzenie materiału mającego strukturę komórkową w roztworze hipertonicznym. Odwadnianie osmotyczne jest stosowane jako obróbka wstępna do odwodnienia żywności przed poddaniem jej procesom takim, jak: zamrażanie, suszenie sublimacyjne, suszenie próżniowe. Zagospodarowanie roztworów po odwadnianiu jest jednym z najważniejszych problemów związanych z odwodnieniem osmotycznym. Syropy po odwadnianiu osmotycznym są zanieczyszczone przez węglowodany, pozostałości z odwodnionego materiału i mikroogranizmy. Celem pracy było zbadanie wpływu obróbki termicznej na zawartość związków fenolowych i czystość mikrobiologiczną syropów sacharozy po 15 cyklach odwadniania osmotycznego owoców borówki wysokiej (Vaccinium corymbosum L.).

Materiał i metody. Materiałem badawczym był roztwór sacharozy $-65,0 \pm 0,5^{\circ}$ Brix użyty w 15 cyklach odwadniania osmotycznego owoców borówki wysokiej (Vaccinium corymbosum L.) odmiany 'Bluecrop'. Odwadnianie osmotyczne prowadzono w temperaturze $40^{\circ} \mathrm{C}$, przez $120 \mathrm{~min}$, stosując owoce wcześniej poddawane wstępnej obróbce enzymatycznej $-70,80,90,100,115^{\circ} \mathrm{C}$ w czasie 20,40 i $60 \mathrm{~s}$. Termiczną obróbkę roztworu sacharozy prowadzono w temperaturze $70,80,90,100 \mathrm{i} 115^{\circ} \mathrm{C}$ przez 20,40 and $60 \mathrm{~s}$. W roztworze analizowano polifenole ogółem, poszczególne polifenole oraz przeprowadzono analizę mikrobiologiczną. Wyniki. Termiczna obróbka w temperaturze $70-115^{\circ} \mathrm{C}$ w ciągu 20 s powodowała degradację od 8,5 do $12,7 \%$ polifenoli w czasie $60 \mathrm{~s}$, natomiast $\mathrm{w}$ temperaturze $115^{\circ} \mathrm{C}$ uległo degradacji $23,1 \%$ polifenoli. Zaproponowano optymalne warunki z punktu widzenia związków fenolowych i jakości mikrobiologicznej: obróbka syropu w $100^{\circ} \mathrm{C}$ przez $40 \mathrm{~s}$. W tych warunkach retencja polifenoli ogółem wynosiła $94,5 \%$, poszczególnych związków fenolowych od 89,2 do 37,2\% i flawan-3-oli 89,5\%. Ten sposób utrwalania syropu pozwolił na obniżenie poziomu drożdży (poniżej $1 \mathrm{CFU} / \mathrm{ml}$ ), a także bakterii termofilnych (poniżej $1 \mathrm{CFU} / \mathrm{ml}$ ).

Słowa kluczowe: odwadnianie osmotyczne, borówka amerykańska, zużyty syrop, polifenole, zanieczyszczenie mikrobiologiczne, obróbka termiczna

For citation - Do cytowania

Kucner A., Papiewska A., Klewicki R., Sójka M., Klewicka E., 2014. Influence of thermal treatment on the stability of phenolic compounds and the microbiological quality of sucrose solution following osmotic dehydration of highbush blueberry fruits. Acta Sci. Pol., Technol. Aliment. 13(1), 79-88. 